International Review of Research in Open and Distributed Learning Volume 21, Number 4

November - 2020

\title{
Writing and Implementing an Open Textbook in World Regional Geography: A Case Study
}

Caitlin Finlayson

University of Mary Washington

\begin{abstract}
As the rising cost of college textbooks has outpaced both inflation and increases in tuition fees, this expense has created a significant barrier to student learning. Some instructors have adopted or created open educational resources, meaning materials which are freely and openly available. While the most obvious benefit of open course content might be cost savings, the fact that these materials can be freely adapted and changed can have substantial impact on the learning experience itself and enable an instructor to completely change the structure and outcomes of a course. This paper provides a case study on writing an open textbook for a course called World Regional Geography and details the writing process and platform options. I also offer practical guidance for faculty interested in authoring open materials and insight into how writing open materials might be framed in terms of a faculty member's larger portfolio of professional activity.
\end{abstract}

Keywords: case study, geography, open textbook, open educational resources, OER, open textbook authoring 


\section{Introduction}

Authoring an open textbook might seem like a tedious endeavour in altruism. By their very nature, open textbooks are free, so they carry neither the professional accolades of traditional texts nor the associated royalty fees. However, writing open educational materials can actually provide significant professional opportunities, from scholarship of teaching and learning research to the possibility of framing the adoption of open content as evidence of reflexive teaching. Furthermore, for faculty passionate about teaching, writing an open textbook can be an enjoyable process of adapting existing course content into a more cohesive narrative form. This paper outlines the authoring and publishing process for an open textbook in geography and provides practical guidance for faculty interested in writing open content.

While much of the research on open educational resources focuses on issues related to efficacy and costsavings, relatively little research has been done exploring open education as pedagogically transformative. By their very nature, open educational resources can be adapted, remixed, and reconfigured to suit individual instructors, and authoring open content for students can provide an opportunity to completely rethink the way a course is designed and taught. As explored in this paper, authoring an open textbook for World Regional Geography enabled a complete shift in pedagogical approach that would not have been possible with a traditional textbook and has yielded a number of significant benefits for students.

\section{Situating Open Textbook Authoring}

It is no secret that the cost of college has risen substantially over the past few decades. But while the high cost of tuition and fees is often highlighted, the cost of textbooks has actually risen at an even faster rate, an increase of 88\% from 2006 to 2016 within the United States according to the Bureau of Labor Statistics (2016). Looking back to the 1970s, textbook costs have actually increased more than $1,000 \%$ compared to today's prices (Popken, 2015). This high cost is having a significant impact on students that is, in turn, affecting the classroom experience for instructors, leading some to adopt or write their own content that is available freely and openly (Bissell, 2009; D’Antoni, 2009; Downes, 2007). Not surprisingly, many proponents of open educational resources (OER) tout the cost savings (see Bliss et al., 2013; Hilton \& Wiley, 2011), but research has also found that students who use open textbooks can have better learning and student success outcomes than those who use traditional texts (Colvard, Watson, \& Park, 2018; Hilton, 2016; Hilton et al., 2016; Bowen, Chingos, Lack, \& Nygren, 2014; Pawlyshyn et al., 2013; Feldstein et al., 2012; Hilton \& Laman, 2012; Lovett, Meyer, \& Thille, 2008). Authoring open content then provides an effective way to address broader learning outcomes and enable a more accessible course experience for students.

As the use and adoption of OER has expanded, so too have guides for prospective authors interested in writing open content. The Open Textbook Network, for example, which manages the widely regarded Open Textbook Library (https://open.umn.edu/opentextbooks/), published Authoring Open Textbooks, a guide for prospective authors and others involved in the adoption of open content (Falldin \& Lauritsen, 2017). The guide, published openly, is free to view and download. BCcampus, another widely regarded organization promoting open education, has the comprehensive Self-Publishing Guide for prospective 
authors which is similarly free and openly available (Aesoph, 2018). Specific institutions also often have information on open publishing, such as Virginia Tech's "getting started" guide, containing a comprehensive list of guides, resources, and groups pertaining to open textbook authoring, editing, and adapting (Virginia Tech, 2019). This paper builds upon existing guides and research to offer a specific case study about the textbook writing process from start to finish as well as practical guidance for how this work might be framed in a professional context.

\section{The Open Authoring Process}

During the summer of 2016, I wrote and published an open textbook for my World Regional Geography course, an introductory undergraduate class. The original goal, however, was not to write an open textbook but instead to revise my course using the backward course design model developed by Wiggins and McTighe (1998), where an instructor begins course planning by considering the desired end results, determines appropriate assessment methods, and plans learning experiences (see Bowen 2017), and to shift to a teambased learning approach, where students work together in small groups to solve real-world problems. Traditional World Regional Geography classes and textbooks essentially take a novice approach to the discipline, focusing on fact-based information about the world and the locations of specific places, most often in a lecture format. For expert geographers, though, it is the connections between places that matter as well as their underlying geographic contexts. What I wanted students to gain from my course and remember years later was not the location of particular cities or rivers but a deeper understanding about how the world is connected and interrelated-essentially an expert understanding rather than a novice approach. With team-based learning, students could come to class, either in person or in a virtual setting, with a basic foundational understanding of core geographic ideas and then apply these concepts to case studies.

One critical barrier to revising the class and adopting a team-based learning approach, however, was the textbook itself. With traditional World Regional Geography textbooks, specific places and particular issues are emphasized over connections between regions and underlying geographic concepts. In essence, they favor breadth over depth. World Regional Geography courses, which typically attempt to teach students, often non-majors, about the geography of the world in a single semester at the 100-level, necessarily have to synthesize and generalize, but rather than accept focus on core ideas of geography and synthesizing where needed, most textbooks seem to concentrate on the details. With this approach, teaching World Regional Geography often feels disconnected-one instructor describes it as "like teaching the encyclopedia"-with no overarching themes tying the world's regions together. Furthermore, emphasizing breadth over depth in a discipline that few students are exposed to before college often leaves them feeling overwhelmed and having difficulty identifying what's important. Other geography instructors have clearly faced similar challenges, as evidenced by a session at the 2019 Annual Meeting of the American Association of Geographers, which was titled: "Teach the World, No Problem: Challenges to Teaching World Regional Geography in One Semester." Using the backward course design model, one of the main revised objectives for the course was for students to learn how to think like geographers and connect concepts across complex world regions; traditional textbooks did not adequately address this goal. 
In exploring my course notes, which I had amassed teaching the course for almost a decade, I realized that my lecture notes themselves would be more useful to students than the textbook I had previously assigned, and, with the addition of a narrative framework, could develop into a textbook of sorts. This notion of not feeling tied to a particular book already in print was pedagogically freeing. If I did not have to follow a particular book's approach and learning outcomes, I could develop entirely new objectives for my course and chapters and write content that specifically addressed these goals.

The first step, then, again following the backward course design model, was to develop overarching course goals, which would become the focus of the textbook and would be woven throughout each chapter. A laundry list of ten learning objectives for the course was whittled down and revised to four specific and measurable outcomes, most notably that students "learn how to think like a geographer by integrating concepts across complex world regions and by synthesizing and analyzing information from a geographic perspective." In addition, a focus on globalization and inequality would provide a cohesive thread to weave the chapters together, avoiding the disconnect that was common in previous iterations of the course.

Next, I developed learning objectives for each chapter. In my experience, the learning objectives featured in traditional World Regional Geography textbooks often seemed tangential to the chapter content. Students rarely made use of them, and they often failed to capture the breadth of the material present in the reading. Instead, I wanted the learning objectives of my chapters to guide the writing of the material, not be written after as a summary of the content. With World Regional Geography, again, most texts emphasized breadth over depth, and thus chapters might include a wide array of content, from physical features to important places to historical events to culture to politics to contentious issues, and the list goes on. For my text, I wanted each chapter to explore a core concept in geography through the lens of a particular world region. In the chapter on Europe, for example, the core concept is migration, and the chapter explores the geography of Europe as it relates to migration-investigating the industrial revolution and the subsequent rural to urban migration, including the physical geography and location of coal deposits, to the modern issues related to nationalism and debates over migration from North Africa and Southwest Asia. Once I established these learning objectives for each chapter, I adapted my course notes, adding a narrative framework, and wrote additional content where needed, but aligned closely with the learning objectives, eliminating any content that was not essential.

The resulting text was far more concise than a traditional geography textbook and, as confirmed by an online survey of students conducted at the end of each semester, was written in a much more approachable style. I was writing for my students, students who are generally not majors and come to my course either uninterested in geography or, worse, with a preconceived idea that they will not enjoy it. Thus, I wrote how I taught, with enthusiasm and in an attempt to convey to students that excitement about the relevancy of geography in today's society. To supplement the text, I added figures and images, most of which were open content that was found online, but some were diagrams I created or photographs I had taken. Open authors can search for images, maps, and figures using Google image search and filter by usage rights, and might also use Wikimedia Commons, public domain imagery and figures from government websites, or Flickr, which also allows searching for images by license. There is a wealth of high-quality open media available online. 
There are a number of platforms for publishing open content and as I already had a personal domain provided by my institution, it seemed like publishing the text as a PDF that could be posted online or printed would be the best approach. I learned LaTeX, which is a free software program for high-quality typesetting, to create the PDF. LaTeX enables the creation of glossaries, figure captions, and tables of contents and is commonly used by academics to write scientific manuscripts. This PDF was then published on my domain, at http://caitiefinlayson.com/worldregional, as well as converted to an HTML file which was also published. Both files were published under the Creative Commons Attribution-NonCommercial-ShareAlike 4.0 International license, meaning the content can be freely copied, shared, and adapted so long as it is not for commercial purposes, the author is attributed, and the material is shared under the same license as the original. Other commonly used open licensing options include the GNU General Public License, often used for software, or simply releasing content into the public domain. Creative Commons content can also be printed by students without concerns about copyright restrictions, so I had our campus bookstore print my textbook in the same way it would print a lab manual or other course pack. The printed, black and white text was available for $\$ 15$ (USD) at our bookstore.

While my intention was simply to create a textbook that would match my desired approach to teaching geography and would enable the use of team-based learning in my class, it became clear soon after posting the book to my domain that the text was of interest to instructors at other institutions. At the time it was published, it was one of only two open textbooks available for World Regional Geography and, including traditional textbooks, was the only one that approached the world's regions using thematic concepts. I began hearing from instructors that adopting my textbook had been similarly pedagogically freeing, enabling them to make use of additional news articles and case studies without overburdening students with lengthy and sometimes irrelevant textbook readings. As of June 2019, the textbook had been downloaded more than 15 , ooo times in over 30 different countries and had been adopted by a number of other institutions.

Now that it is clear the textbook has reach far beyond my class, I want to ensure the book is fully accessible. While LaTeX enables the creation of a high-quality PDF, it does not create an accessible document and does not support the use of alternative text (or "alt text"), for instance. In addition, while I have updated some maps to optimize black and white printing and to ensure a color scheme compatible with students who might be color blind, many black and white images and maps in the course pack from the bookstore were low quality. To address these issues, I will be shifting to hosting the textbook on Pressbooks, a platform for creating open content. Pressbooks will allow me to create a text that is fully accessible and will, unlike my current PDF, be optimized for any viewing platform. If students want to access the textbook on their mobile device, for example, it will be much easier to browse and scroll through. In addition, Pressbooks allows users to export files for publishing with print-on-demand services, so students at my university and other institutions will be able to order a full-color version of the textbook for around $\$ 40$ depending on the printon-demand platform. The text will still be fully open and free online and will continue to be published under the Creative Commons license. 


\section{Open Authoring as Professional Activity}

Though authoring open educational materials might not "count" as scholarly research in the traditional sense for tenure and promotion, there are a number of other ways faculty can get credit for work creating open content. In this section, I explore several possibilities for framing the authoring of open content within the context of a faculty member's professional activities.

\section{Scholarship of Teaching and Learning}

Within the realm of scholarly activity, authoring open educational resources provides a robust opportunity for faculty to develop research projects on the scholarship of teaching and learning. Faculty could consider situating their projects within the COUP Framework developed by the Open Education Group, exploring the issues of cost, outcomes, use, and perceptions of open educational materials (Open Education Group, n.d.). In this way, although an open textbook itself might not be peer reviewed, it could enable peerreviewed research regarding its development and implementation. Faculty could apply for institutional review board approval to survey students about their use of the open resource. In my own course, for instance, I conducted an online survey of students about their perceptions of open educational materials before and after the semester began, finding that students are significantly more likely to rate open textbooks as better than traditional texts at the end of my course. Other projects might explore the costs of open textbooks and how frequently (or infrequently) students actually buy the required materials for their courses. Faculty could also work collaboratively within departments or across institutions to develop open course materials and exchange ideas.

Depending on the institutional framework and disciplinary expectations, these scholarly works might not carry the same weight as traditional publications, but could provide additional peer-reviewed scholarship as part of a larger portfolio of professional work. Moreover, if the criteria for promotion to full professor is recognition outside of the university, publishing open content could provide an opportunity for a faculty member to reach a much broader audience and network beyond a small disciplinary circle. There are numerous conferences both on open education, such as the annual Open Education Conference, as well as on the scholarship of teaching and learning, such as the annual conference of the International Society for the Scholarship of Teaching and Learning (ISSOTL). Even within disciplines where the scholarship of teaching and learning is not as valued as traditional academic scholarship, publications on open education and pedagogy are often themselves published openly and might be more widely read than disciplinary scholarship. Finally, faculty could consider publishing about open education within disciplinary pedagogical publications. In geography, for example, there are a number of peer-reviewed publications concerning pedagogical scholarship which include The Journal of Geography and the Journal of Geography in Higher Education.

\section{Reflective Teaching}

If disciplinary norms or institutional expectations limit the viability of publishing about open authoring or its implementation in a pedagogical journal, faculty could consider framing open authoring as evidence of reflective teaching practice, a common facet of tenure requirements. If traditional evaluation instruments are used, faculty could examine comments regarding the use and adoption of open materials in particular. In my own course, for example, evaluations improved after the adoption of the open textbook. Evaluation 
responses can be framed in terms of teaching efficacy and used as evidence of reflective and adaptive teaching. Instructors might also consider checking with their institution's center for teaching and learning, if one exists, for further guidance on framing open resource adoption in terms of teaching effectiveness within the particular institutional culture.

\section{Fellowship and Grant Opportunities}

Faculty could consider making use of grant opportunities to support the authoring of open materials, both internally and externally. Internal grants might not reference open content in particular, but instead focus on innovative teaching or pedagogical development. For my textbook, for example, I successfully applied for an institutional pedagogy improvement grant to add more active learning opportunities to my course, with no intention of authoring a textbook. However, as mentioned, the initiative to develop more active learning and flip my course eventually developed into a textbook authoring project. This could have easily been written into the grant application on the outset and the pedagogical improvements framed in terms of the open content. There is ample research on the benefits of open content adoption from cost savings to learning outcomes, and grant applications can reference this scholarship. External funding opportunities could include a fellowship with the Open Education Group, an exceptional opportunity especially for faculty who are interested in authoring open content but who might be new to research into open educational materials. States might also have specific initiatives to fund open content authoring and adoption. Faculty might check with their university library as a resource. Virginia's Academic Library Consortium (VIVA), for example, offers course redesign grants to fund the adoption and creation of open content (see VIVA, 2019) and a number of states have similar initiatives.

\section{Conclusion}

Authoring an open textbook can certainly seem daunting. After all, if a paper can take several weeks (or more) to write, authoring a textbook would seem an almost impossible challenge. But there are a number of key differences between writing an academic manuscript and authoring an open textbook. For one, depending on the book, it may be written in a much more conversational style, which can make writing it quite enjoyable. I found myself writing the book as if I were having a conversation with a student and intentionally tried to keep my voice present. In addition, the open textbook likely focuses on content you may have taught numerous times before. Thus, while there might be gaps in knowledge that need shoring up or cross-referencing of key facts and figures, you probably know far more about the material than you realize. You know where students often make mistakes and what might need to be explained more. You know what students enjoy and what you might elaborate on a bit more. You know how to teach the material in a way that makes connections with what students have learned before. All of these key pieces equate to a positive writing experience that might be, at times, little more than creating a narrative framework around lecture notes that you have refined and tweaked for the past decade. Finally, though ideally the same could be said of traditional scholarly research projects, the open textbook content likely concerns information you are deeply passionate about and knowing that the open content is going to be of substantial benefit to your students can be highly motivating. 
It is important to remember that you do not have to embark on open authoring alone. By the very nature of open content, other faculty who have written open materials are likely to be very willing to share advice and guidance with prospective authors. I have been amazed by the generosity of other open authors when I have reached out with questions. Furthermore, open content can be remixed and adapted, so open authoring does not have to constitute sitting down to a blank screen and typing a manuscript from scratch. Rather, you can find and make use of existing open content and remix it to fit particular course goals and objectives. You will likely find the open authoring process a supportive and positive academic endeavor.

As state legislatures and institutions move toward the adoption of open content in institutions of higher education, additional opportunities to fund the authoring of OER will likely arise. Even absent funding, however, you can find ways of framing the authoring of open content as part of a larger portfolio of professional academic activity. Open authoring can provide a gateway into a new avenue of pedagogical scholarship and can open the window of possibility into teaching innovations that might not be possible with traditional texts. Authoring an open textbook, which enabled a complete overhaul of my course, transformed the way I teach and continues to shape my professional career.

\section{Acknowledgements}

This study is supported, in part, by an Open Education Group fellowship. 


\section{References}

Aesoph, L.M. (2018). Self-publishing guide. Victoria, BC: BCcampus. Retrieved from https://opentextbc.ca/selfpublishguide/

Bissell, A. (2009). Permission granted: Open licensing for educational resources. Open Learning: The Journal of Open, Distance and e-Learning, 24(1), 97-106. doi: 10.1080/02680510802627886

Bliss, T., Hilton, J., Wiley, D., \& Thanos, K. (2013). College student and faculty perceptions of the cost and quality of open textbooks. First Monday, 18(1). doi: 10.5210/fm.v18i1.3972

Bowen, Ryan S. (2017). Understanding by design. Vanderbilt University Center for Teaching. Retrieved from https://cft.vanderbilt.edu/understanding-by-design/

Bowen, W. G., Chingos, M. M., Lack, K. A., \& Nygren, T. I. (2014). Interactive learning online at public universities: Evidence from a six-campus randomized trial. Journal of Policy Analysis and Management, 33(1), 94-111. doi: 10.1002/pam.21728

Bureau of Labor Statistics. (2016). College tuition and fees increase 63 percent since January 2006. Retrieved from https://www.bls.gov/opub/ted/2016/college-tuition-and-fees-increase-63percent-since-january-2006.htm

Colvard, N. B., Watson, C. E., \& Park, H. (2018). The impact of open educational resources on various student success metrics. International Journal of Teaching and Learning in Higher Education, 3o(2), 262-276. Retrieved from https://files.eric.ed.gov/fulltext/EJ1184998.pdf

D'Antoni, S. (2009). Open educational resources: Reviewing initiatives and issues. Open Learning: The Journal of Open, Distance and e-Learning, 24(1), 3-10. doi: 10.1080/02680510802625443

Downes, S. (2007). Models for sustainable open educational resources. Interdisciplinary Journal of Knowledge and Learning Objects, 3(1), 29-44. doi: 10.28945/384

Falldin, M. \& Lauritsen, K. (2017). Authoring open textbooks. Open Textbook Network. Retrieved from https://press.rebus.community/authoropen/

Feldstein, A., Martin, M., Hudson, A., Warren, K., Hilton III, J., \& Wiley, D. (2012). Open textbook and increased student access and outcomes. European Journal of Open, Distance, and E-Learning, 15(2). Retrieved from https://www.eurodl.org/materials/contrib/2012/Feldsteint_et_al.pdf

Hilton III, J. L. (2016). Open educational resources and college textbook choices: A review of research on efficacy and perceptions. Educational Technology Research and Development, 64(4), 573-590. doi: $10.1007 / \mathrm{s} 11423-016-9434-9$

Hilton III, J. L., Fischer, L., Wiley, D., \& Williams, L. (2016). Maintaining momentum toward graduation: OER and the course throughput rate. International Review of Research in Open and Distributed Learning, 17(6), 18-27. doi: 10.19173/irrodl.v17i6.2686 
Hilton III, J., \& Laman, C. (2012). One college's use of an open psychology textbook. Open Learning: The Journal of Open, Distance and e-Learning, 27(3), 265-272. doi: 10.1080/02680513.2012.716657

Hilton III, J. \& Wiley, D. A. (2011). Open access textbooks and financial sustainability: A case study on Flat World Knowledge. International Review of Research in Open and Distance Learning, 12(5), 18-26. doi: 10.19173/irrodl.v12i5.960

Lovett, M., Meyer, O., \& Thille, C. (2008). The Open Learning Initiative: Measuring the effectiveness of the OLI statistics course in accelerating student learning. Journal of Interactive Media in Education, 14, 1-16. Retrieved from https://files.eric.ed.gov/fulltext/EJ840810.pdf

Open Education Group. (n.d.). The COUP framework. Retrieved from http://openedgroup.org/coup

Pawlyshyn, N., Braddlee, B., Casper, L., \& Miller, H. (2013, November 4). Adopting OER: A case study of cross-institutional collaboration and innovation. EDUCAUSE Review. Retrieved from https://er.educause.edu/articles/2013/11/adopting-oer-a-case-study-of-crossinstitutionalcollaboration-and-innovation

Popken, B. (2015). College textbook prices have risen 1,041 percent since 1977. NBC News. Retrieved from https://www.nbcnews.com/feature/freshman-year/college-textbook-prices-have-risen-812percent-1978-n399926

Virginia's Academic Library Consortium (VIVA). (2019). VIVA course redesign grant program: Spring 2019 awards. Retrieved from http://vivalib.org/c.php?g=836990\&p=6638954

Virginia Tech. (2019). Open education: Open textbook authoring and editing. Retrieved from https://guides.lib.vt.edu/oer/authors

Wiggins, G., \& McTighe, J. (1998). Understanding by design. Alexandria, VA: Association for Supervision and Curriculum Development. Retrieved from http://www.ascd.org/Publications/Books/Overview/Understanding-by-Design-Expanded-2ndEdition.aspx

\section{Athabasca University}

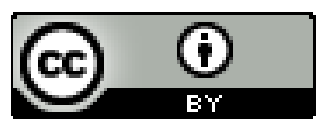

